\title{
Treading paths to sustainability: an analysis of the postgraduate curriculum in Business Administration
}

\author{
Carolina Sampaio Marques $^{1^{*}}$ (D), Marcelo Trevisan ${ }^{2}$ and Anderson Cougo da Cruz $^{2}$
}

\section{${ }^{*}$ Correspondence:}

carolinamarques@unipampa.

edu.br

${ }^{1}$ Federal University of Santa

Maria and Federal University

of Pampa, Av. Pedro

Anunciação, s/n - Vila Batista

District, Caçapava do Sul, RS

96570-000, Brazil

Full list of author information

is available at the end of the article

\begin{abstract}
Education for Sustainability is seen as a powerful catalyst for change and social transformation aimed greater equity in the relations between society and the environment. In this way, the higher education institutions are responsible in this process. The purpose of this study is analyzing the present elements in the post-graduation programs in Administration that enhance the formation of professionals committed to sustainability. Thus, a documental research was conducted that examined the pedagogical projects of eight programs of master degree in Business Administration that were already implemented in Rio Grande do Sul, Brazil. It was concluded that the pedagogical projects of the courses are committed to the thematic of regionalities and sustainable issues, but when that aspect is transferred to the discipline of the courses, this query cannot be measured directly. Besides, they identified which were the subjects more related with the sustainability theme, the relationship between compulsory subjects, research lines and Education for Sustainability.
\end{abstract}

Keywords: Education for Sustainability, Pedagogical projects, Master's in Business Administration, Rio Grande do Sul—Brazil

\section{Background}

The twentieth century brought about the growth of a community that began to be concerned about the degradation of the environment due to development at the time. The spread of environmental problems, tied to the societal influence in this process, brought about a new concept called sustainability. This concept has spread and rooted itself in the past 20 years, causing initial disconcertion, but later generating impact and legitimacy, molding the realm of public decisions (Bursztyn and Drummond 2009).

Thus, the present moment requires that society is motivated and mobilized to assume a propositional character and to this end, is important the strengthening of organizations and public institutions, such as universities, to build institutions guided by a sustainability logic.

It can be seen throughout the world that various educational institutes have begun to understand the necessity of being more sustainable, serving as a model for the adoption of green practices (Clugston 2004). These practices occur in the university

(C) 2016 Marques et al. This article is distributed under the terms of the Creative Commons Attribution 4.0 International License (http://creativecommons.org/licenses/by/4.0/), which permits unrestricted use, distribution, and reproduction in any medium, provided you give appropriate credit to the original author(s) and the source, provide a link to the Creative Commons license, and indicate if changes were made. 
administration, considering the infrastructure and training, as well as a method of inclusion in majors and projects.

According to Wright (2004) multiple universities in the world have signed declarations of commitment to sustainability; moreover, the importance that universities have to bring about necessary changes is noteworthy. For Clugston (2004), universities have the responsibility to teach about social problems, besides leading debates about these issues with the goal of proposing solutions. University education should question reality, stimulating the development of new knowledge, habits, and values, and producing more conscious citizens who contribute for a better world. In this same line of reasoning, Lauder et al. (2006) point out that education is an important tool for the preparation of individuals in order to have a sustainable society.

In this sense, Education for Sustainability comes about as one of the ways to support the process of awareness and understanding of the current challenges. Tilbury (2004) argues that the premise of Education for Sustainability will only be viable when institutions and instructors rethink their roles as agents of change. Therefore, in order for them to be professionals with participative and holistic views of society, it becomes necessary to think about the training of teachers and professionals, in a way that we understand how these parties can stimulate critical thinking and synchronize with the necessities of the job market, with the aim of preparing for a sustainable future. In this way, professional education comes to need new components, with sustainable perspectives, focused on responding to the environment in which they are found.

\section{Problem analysis}

The purpose of this study is analyzing the present elements in the postgraduation programs in Administration that enhance the formation of professional committed to sustainability To do this research, eight MBA programs were studied, all of which are located in the state of Rio Grande do Sul, Brazil.

Various studies have analyzed the issues of sustainability in Master's programs. In a study carried out by Mochizuki and Fadeeva (2010) there is a description of a project carried out by Columbia University to complete the Master's guided through the lens of Sustainability. The study from Latif et al. (2015) (20) examines the experience of adding into the Master's of Science at City College of New York a specific qualification in terms of sustainability through interdisciplinary curriculum and of professionals. The researchers that analyzed the Master's programs contribute initiatives that study programs created with a focus on sustainability; however, the intention of this paper is to analyze programs in which the introduction of knowledge about sustainability is not an end activity, but rather, additional knowledge that should be integrated throughout programs and by professors.

In the reviewed literature, we did not find any studies similar to this one, that have the intent to analyze the pedagogy projects of MBA programs in Brazil from the point of view of sustainability and its contribution, which can be built on for future studies aimed at improving the education of teachers and professionals in the area of business. It is belied that the lack of studies like this is due the format that the Masters courses in administration are conduced once they still form professional focused on market perspective and with values focused in the economic aspects of the market instead of in the 
perspective of sustainability. In this process sustainability is still not an issue considered important for all students and teachers, being just a focus point of research for some teachers. There is also a lack of legislation obliging the subject in the Masters Courses, as well as in the graduation courses in Brazil. Thus, the gaps in the literature and the importance of this issue for the future teachers and education managers are the motivations for this study.

Although sustainability permeates not only the daily lives of the population in general, but also the instruction in MBA programs, and even with a diversity of initiatives and approaches and the consolidation of the introduction of sustainability in business schools, continues to be a challenge for universities (Godoy et al. 2013).

The role of universities, in this context, is important not only because their research and instruction generate the transfer of knowledge about sustainability, but also because they educate future professionals with potential to contribute to a sustainable future (Barth and Rieckmann 2012). In this way, instigating debates and generating consistent information about existing problems and relating them to professional education can contribute to the creation of a more just and sustainable society. In this sense, the introduction of this theme in Master's programs' curricula can be a way to initiate the process of awareness through the training of professionals who will be future instructors and who will disseminate the knowledge acquired through their education.

This paper is divided into six parts, with the background being the first. After, there are problem analyses and discussion of the creation of a curriculum based on sustainability in MBA schools, and in the fourth part, the methodology of this study will be found. The fifth part will cover the discussion about the theme, and in the final phase conclusions about this study will be presented.

\section{The creation of a 'green' curriculum}

The sustainability requires an inter-relation between social justice, life quality, environmental balance as well as the rupture with the current development pattern (Jacobi 1997). Thus, the introduction of sustainability in the curricula is not an easy task for Business schools. For Springett and Kearins (2005), the problem with introducing sustainability in the curricula of MBA degrees lies in the ideological fight that seeks to contest the "legitimacy" and the legacy of orthodox business theory. However, the awareness that sustainability is a necessary process for society makes it essential to include this concept in the curricula of business schools in such a way as to create opportunities for workers, managers, and professors to acquire knowledge that aids in sustainable progress.

Brazil does not utilize the term Education for Sustainability in its legislation and rules, in which the term Environmental Education is used, when reference to the introduction of environmental topics in educational policy is used. The document named "Education for a Sustainable Future" affirms that the origins of Education for Sustainability are rooted in Environmental Education (UNESCO 1999). The Agenda 21, a report created from the Eco-92 Conference that instituted a global and local sustainable development plan, establishes a relationship between Education for Sustainability and Environmental Education. In Chapter 36 of the report, there is a recommendation for the necessity of integrating these concepts (Hesselink et al. 2000). Thus, in this study, we will adopt 
the idea that Education for Sustainability is an evolution of Environmental Education, according to Hesselink et al. (2000), and these two terms can be used in this paper in an equivalent manner.

An example of the incorporation of Environmental Education in Brazilian educational policy is Law $n^{\circ} 9.795 / 1999$ (Brasil 1999) that pertains to questions related to sustainability in an interdependent manner. This Law considering the natural, social, economic and cultural environments interlinked which demonstrates conceptions of sustainability that interlink and relate to each other in a holistic and integrated way. This conception is in accordance to the ideas of Education for Sustainability available in international documents (Sleurs 2015; UNESCO 2005).

The aforementioned legislation establishes the obligatory inclusion of Environmental Education as an integrated, continuous, and permanent educational practice at all levels and modalities of formal education (art. 10), and, furthermore, determines the requirement to be present in all curricula in teacher training, at all levels and in all subjects (art. 11). Barbieri (2004) believes that the topic can be conceived as a transversal axis, spreading throughout various Business Administration higher education programs, wherein one specific class about the topic should be offered in graduate programs in Business Administration. In practice, what is seen differs from theory, as the content related to environmental education should be incorporated as a transversal axis; it does not belong directly to the areas of instruction and this complicates the incorporation of this topic, in elementary and secondary education in Brazil. In higher education, this topic is one of the points of evaluation of the program in accordance with the Ministry of Education, and, for this reason, it appears in the curricula and pedagogy of those institutions.

Given the necessity of including sustainability in formal education, reflecting upon the training of professionals who are concerned about socio-environmental problems becomes one of the educational responsibilities of institutions of learning. de Castro (2000) comments that universities are relevant spaces for the production of knowledge, and should focus their work in search of socio-environmental solutions, as the delay of the production of knowledge and of the access to this knowledge by others, can be decisive in the sense of generating detriment to the new generations.

By putting sustainable preconditions in higher education, Fouto (2002) believes that there will be an advancement of education as an important element for the incorporation of values and ethical behaviors and that it will contribute to the mobilization and integration among those involved. Fouto (2002) further suggests the inclusion of some practices at universities, like: (1) sustainable internal procedures; (2) environmental training for instructors; (3) awareness of the population involved with the sustainable practice; (4) dissemination of the knowledge generated both inside and outside of the walls of the institution; (5) incentive for research with an eye towards sustainable development in an interdisciplinary form; (6) commitment of all involved to ethics and social responsibility; (7) training of partners with other institutions of higher education and with other sectors of society.

In the same vein, Paulo and Ferolla (2010) believe that the education in MBA programs must have the principle of providing a vision that transcends pure and simple utilitarianism and that goes on to evaluate the benefits of the decision-making in direction towards sustainability. For this reason, as de Andrade et al. (2000) claim, Business Administration 
programs, at the undergraduate and graduate levels, should take new professional education classes into consideration in their curricula, and therefore, in new pedagogical project disciplines in professional education of Administrators; including environmental management, in order to accompany the changes and needs of today's world.

Multiple authors have commented about the importance of evaluating the curriculum of a program in relation to sustainability in order to facilitate a greater inclusion and integration of key concepts (Sterling and Thomas 2006; Segalàs and Mulder 2010). A study carried out by Brandli et al. (2014), in an analysis of several undergraduate programs, identified the necessity of incorporating ideas and sustainability in an interdisciplinary and transdisciplinary manner, and furthermore maintained the need for sustainability to be present in campus life. Thus, there is a clear need to analyze the curricula of various programs with the intention of identifying weakness and growth opportunities.

A study conducted by Figueiró and Raufflet (2015) differentiates the incorporation and the integration of sustainability concepts in curricula. The authors maintain that integration is the adoption of sustainability in a holistic and transversal way into the programs. On the other hand, incorporation is the adoption of the topic in a sparse and superficial manner, without the intention of rethinking about the curriculum in a sustainable fashion.

Yet Amorim and Custódio (2010) point to a negative aspect in this process of 'greening' the curriculum: there is an absence of classes, professors, and even a socio-environmental vision in higher education institutions in order to offer a holistic approach for MBA programs, which leaves fewer opportunities for the student body to articulate this wide vision about the participation and direct intervention in private companies in dealing with socio-environmental issues.

In accordance with Junior et al. (2014), in which they refer to MBA programs, some inclusions of sustainability in MBA programs in the United States can be identified; however, in Brazil, this area is not yet on solid ground. Many authors have commented on the difficulties that exist in including this topic in MBA programs, such as: (1) the issue of the interdisciplinary nature of the theme, which complicates the effective implementation of the subject (Jacobi et al. 2011); (2) a more systematic vision which considers learning based on a more concrete participation by the various stakeholders involved (Jacobi et al. 2011); (3) an introduction of new forms of teaching and learning (Gonçalves-Dias et al. 2013); (4) obstacles to the creation of a new curriculum (Leal Filho 2011), among others. The authors Benn and Dunphy (2009) further this analysis in claiming that in sustainability education in business schools, the theme of sustainability is not systematically integrated, being restricted to only one elective class during the course.

Another difficulty in the integration of this topic is pointed out by Springett (2005) in which she identifies the difficulty for the students to understand that sustainability is not only a discourse about ecology and economy, but it is rather primarily ideological and political. Education for Sustainability involves a process of critical investigation that encourages people to explore the complexity and the implications of this approach in light of economic, political, social, cultural, technological, and environmental forces that either foster or prevent it (Godoy et al. 2013). For Venzke and Nascimento (2013), 
it is necessary that the Brazilian higher education institutions that educate administrators widen their current epistemological base so that they are able to resolve, in a more complex manner, the issues related to socio-environmental sustainability. In this study, the concept of sustainability has been approached from the perspective that involves the breakdown of existing standards in a look that aims to stimulate critical thinking to raise awareness of issues related to different aspects of sustainability.

Many times, the integration of environmental variables in the pedagogical projects of MBA programs is seen as a negative factor, since it threatens the competitiveness of organizations (Demajorovick and Silva 2012); however, according to the cited reference, this becomes a process through which all institutes of learning should pass.

In the following section, the methodology that was adopted for the completion of this paper will be described. The type of research, the form of data acquisition, and the mode of analysis of the data will be described.

\section{Methods}

Keeping in mind the purpose presented in the problem analysis, it is interesting to ascertain how pedagogical projects in Master's Administration programs incorporate questions about sustainability in their curricula and courses. We chose to research MBA programs due to the fact that this type of program is responsible for training professionals that can change the reality of the institutions that they will manage. Moreover, these institutions also certify professors who will train business professionals in the future. Godoy et al. (2013) affirm that the trajectory toward Education for Sustainability in business schools is marked by a series of conflicts, at the macrostructural, collective level, as well as at the individual level. These conflicts will permeate the entire proposal of change in the curriculum, and in the training of instructors for MBA programs, as well as what happens inside the classrooms.

The choice to study Master's program in Rio Grande do Sul was made due to geographic questions, given that there are different socioeconomic regions, with ethnic, cultural, and economic differences, and with various levels of industrialization, which the authors believe can faithfully represent the state. In the other states in Brazil, the majority of MBA programs is in metropolitan regions and has a large contingent of the population that cannot show such a truly representative context.

In accordance with the proposed objectives, this is descriptive research, as defined by Roesch (2005); descriptive research has, as a primary objective, the acquisition of information about a particular population or phenomenon. This type of research gathers the necessary information for action or prediction. To reach the proposed objective, we conducted documental research through the analysis of pedagogical projects and classes of the Master's programs in question. As the first phase of research, we looked on the website of the Brazilian Research Assessment Agency-CAPES (http://www.capes.gov. br/cursos-recomendados) to find out how many and which MBA programs exist in the state of Rio Grande do Sul, Brazil; according to this site, there are eight academic MBA programs currently functioning, located on Fig. 1.

Having this information, as a next step in the study, we conducted research on the website Sucupira Plataform (https://sucupira.capes.gov.br/sucupira/), searching for the 


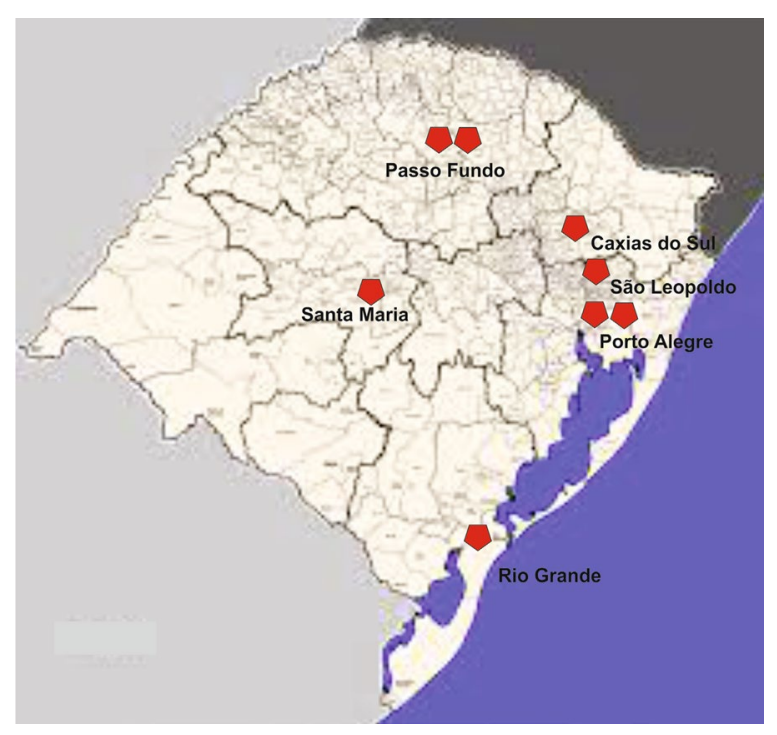

Fig. 1 Map of the state with the location of the Master's programs. Source: Created by the authors based on the data from CAPES

pedagogical projects of the eight programs previously identified on the CAPES website. The Sucupira Plataform is a tool for public access where Brazilian graduate programs make information available about their programs. This site is of obligatory completion on the part of the programs and it aims to bring greater publicity and transparency of information about graduate programs.

Based on that, the pedagogical projects were read in full and a qualitative analysis was used, based on the Bardin (2004) content analysis. The author should precede encoding the raw data, creating an array of categories or recording units, building frames for the organization and presentation of the data collected. Furthermore, a descriptive searched data analysis was performed. Microsoft Excel software was used for compile data, scores and drafting tables. To perform content analysis, categories based on theoretical references were created. Therefore, the created categories for research variables identification are specified in Table 1.

After that, we conducted an analysis of all of the pedagogical projects and the registered classes in each previously specified program, looking to identify if the theme of sustainability was present and also the presence of classes related to the subject. Firstly, we conducted an analysis of the text of the pedagogical projects with the intention of finding connections with sustainability and, in the next phase, we read the syllabi of each course, with the intention of finding proximity of the disciplinary content with sustainability. After these stages, the sites of the graduate programs were consulted, aiming to confirm information with respect to the lines of research of each program and if the course related to them was required or elective. Figure 2 specifies the stages carried out in this research.

As much information was retrieved directly from public sites, we opted not to name the universities in this paper. The data-collection period was from June 2 to August 11, 2015. 
Table 1 Analysis of categories

\begin{tabular}{|c|c|c|}
\hline Category & Category description & Authors \\
\hline Sustainable curriculum & $\begin{array}{l}\text { Analyzes how sustainability is } \\
\text { approached in the pedagogical } \\
\text { projects of the masters in admin- } \\
\text { istration }\end{array}$ & $\begin{array}{l}\text { Springett and Kearins (2005), Sterling } \\
\text { and Thomas (2006), Segalàs and } \\
\text { Mulder (2010) }\end{array}$ \\
\hline Disciplines related to sustainability & $\begin{array}{l}\text { It describes if there are disciplines } \\
\text { that address issues of sustainability } \\
\text { and if this course is mandatory for } \\
\text { all students }\end{array}$ & Barbieri (2004), Jacobi et al. (2011) \\
\hline \multirow[t]{4}{*}{$\begin{array}{l}\text { Concepts of sustainability inserted } \\
\text { and integrated }\end{array}$} & $\begin{array}{l}\text { Analyze if sustainability is } \\
\text { approached along with other } \\
\text { subjects or in isolated }\end{array}$ & $\begin{array}{l}\text { Figueiró and Raufflet (2015), Brandli } \\
\text { et al. (2014) }\end{array}$ \\
\hline & $\begin{array}{l}\text { There is specific line of research on } \\
\text { sustainability }\end{array}$ & \\
\hline & $\begin{array}{l}\text { This is issue specific for any line of } \\
\text { research or a general theme }\end{array}$ & \\
\hline & $\begin{array}{l}\text { Also disclosed is inserted content } \\
\text { in the subjects that are related to } \\
\text { sustainability }\end{array}$ & \\
\hline
\end{tabular}

Source: Elaborated by the authors based on the theoretical references

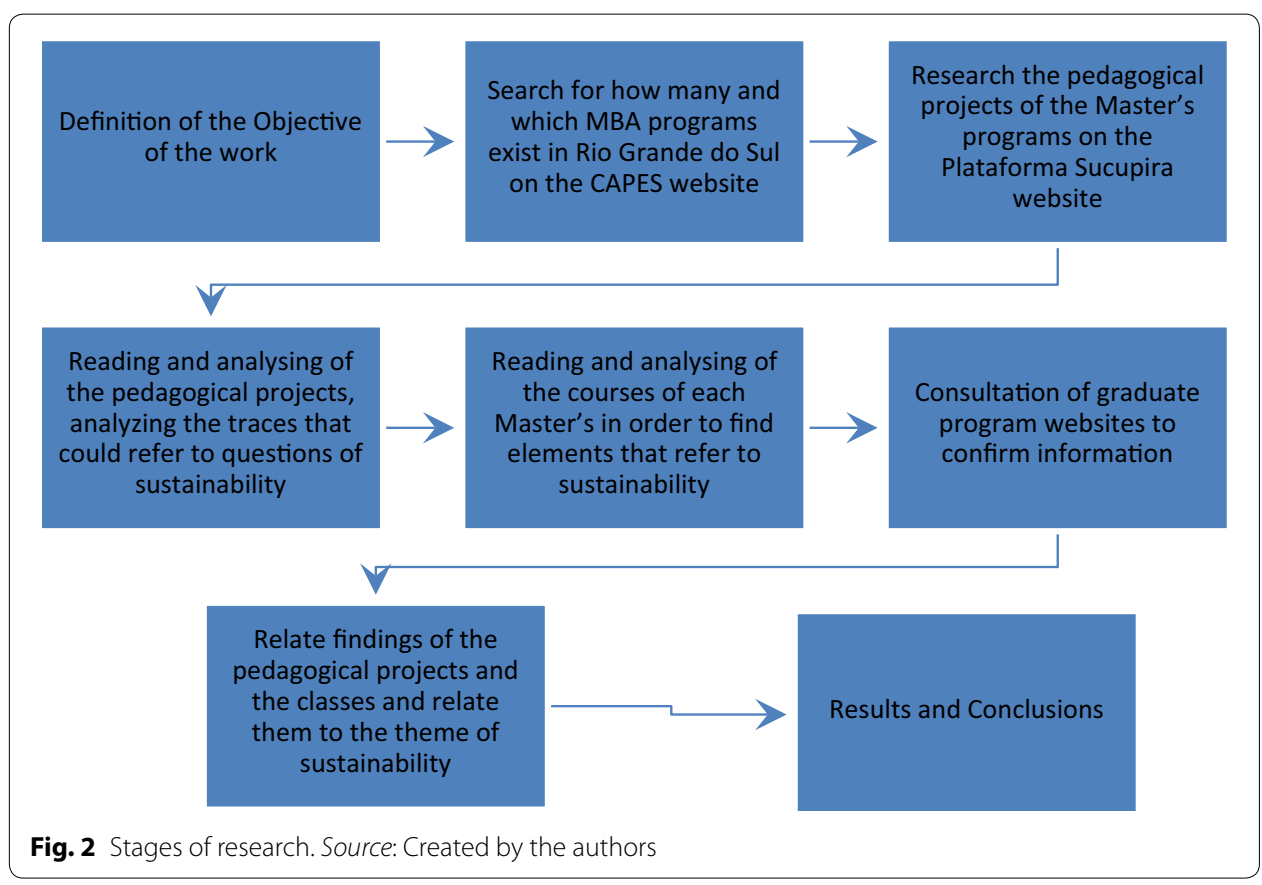

\section{Results and discussion}

MBA programs in Rio Grande do Sul

MBA programs have the characteristic of a plurality of topics covered in the education of the professionals, whether they are professors or managers. Within this range of courses, a large part is related to psychological, sociological, anthropological, economic, and environmental factors.

In this sense, the MBA programs in Rio Grande do Sul, along with other programs; have the challenge of collaborating with society based on socially and environmentally 
responsible behaviors and the improvement of skills, values and human competencies for an authentic participation in the decision-making process of those that knock on the door in search of new knowledge (Salgado and Cantarino 2006).

The pedagogical projects that were researched have a close relationship with the geographic location of each Master's program. It is generally accepted that, within the content, there exists the aim of preparing the local workforce, always paying attention to the problems and particularities of the region in which they are located. This demonstrates the incorporation of the program within the local area and the awareness of the importance of valuing the local factors, such as the culture and the necessities of a community that seeks the training.

Another finding is that the researched projects do not only have the goal of educating professors, but there is also a focus on training professionals and managers, as this is an academic Master's program. All of the curricula state the intention of educating professionals who will train for the job market, whether for organizational management, or for a career in education. This aspect demonstrates that the education obtained in the Master's programs aims at the training of professionals with multiple functions within an organization and with a profile related with the complexities of the environment.

The relationship with sustainability is seen in six of the eight analyzed projects. The majority of the projects understand the necessity of considering, in a more integrated way, the knowledge of sustainability. These projects mention issues such as the integration of knowledge, the need for studies that are more related to sustainability, and the applicability of these concepts to the science of Administration. This aspect will be further analyzed when we refer to the courses of each program. Another point that bears notice is that in four programs, there are research groups that have sustainability as one of their areas.

It also emphasizes that the surveyed pedagogical projects does not mention any activity that has the interdisciplinary focus and establishes relationships between disciplines, research areas or even other courses. As pointed Latif et al. (2015) for projects in sustainability to succeed, it is necessary to establish interdisciplinary relationships between different fields of science.

In the following section, we will analyze the specific classes of the graduate programs in Rio Grande do Sul, and their relations with sustainability. The purpose of this is to identify if the adopted discourse of the pedagogical project is reflected in the classes, since the authors understand that one of the ways of visualizing the conception of a program is by analyzing how the classes are related to the concepts identified in the curriculum.

\section{Analysis of the courses in Business Administration graduate programs}

In order to carry out the analysis of the individual courses of graduate programs, we chose to utilize information specified in the Sucupira Plataform; then, after acquiring the curricula of the analyzed programs, it was chosen to analyze descriptively the number of disciplines, as explained in Table 2.

Table 2 shows the number of existing courses for each MBA program and the number of courses that covered themes related to Sustainability in some format. Thus, it is noted that there are few disciplines in the programs that relate to the theme of sustainability. 
Table 2 Amount of courses in graduate programs in Business Administration

\begin{tabular}{llll}
\hline Master's & $\begin{array}{l}\text { Number of classes } \\
\text { in the curriculum }\end{array}$ & $\begin{array}{l}\text { Number of classes with } \\
\text { Sustainability topics }\end{array}$ & $\%$ \\
\hline MBA 1 & 23 & 2 & 8.7 \\
MBA 2 & 20 & 1 & 5 \\
MBA 3 & 67 & 6 & 8.9 \\
MBA 4 & 25 & 2 & 8.0 \\
MBA 5 & 33 & 3 & 9.0 \\
MBA 6 & 17 & 0 & 0 \\
MBA 7 & 44 & 6 & 13.6 \\
MBA 8 & 24 & 4 & 16.6 \\
\hline
\end{tabular}

Source: Developed by the authors based on research data

Only two of the eight masters have over $10 \%$ of disciplines with the issue in question. It can be seen that, in general, there is little integration of the theme into the graduate programs, seeing that this is a multidisciplinary topic and can be used in many subjects and theories. We can observe also that there is no mention of the subjects related to sustainability in the syllabi of the program, which worries us due to the fact that these programs are trainers of professionals that will perform key functions in companies and universities. Furthermore, it must be noted that in the majority of these programs there is a class of special topics, that normally have flexible content and that could be used to approach new content, such as this theme.

It is also important to state that in University 7 and University 3, there are two subjects (Sustainable Operations Management and Research Methods in Innovation, Technology and Sustainability, respectively) that in spite of the name of the subjects being related to topics about Sustainability, the syllabi do not cover any topics in this respect, and for this reason, these two are not shown in Table 2.

To arrive at the number of courses that cover themes related to Sustainability, we analyzed each syllabus, attempting to find words that identify the theme, that upon seeing this word, naturally was identified with the subject. We were careful to only identify words that, within the context of the sentence, had a connotation identified with sustainability. Thus, the Table 3 identifies words directly related to the theme in question that were found in the course syllabi of the MBA programs.

Table 3 provides a list of words and the number of times that they appear within the disciplines of the masters. It is observed that the most used words represent concepts on the subject (such as sustainability which appears 22 times; social responsibilityten times and sustainable development-eight times) which may point that there is an attempt by the programs put concepts of sustainability and sustainable development for the qualification of professionals involved in this context.

We can also see that there is an integration of specific concepts about the topic, like Green IT, reverse logistics and social capital, which can demonstrate the intention to expand the knowledge about this topic and also that there are professionals in specific areas that possess the capacity to transmit this knowledge to students. Furthermore, it is of utmost importance that university administrators and faculty realize the importance of these courses in the curricular structures of their programs, since, according to 
Table 3 Words used to demonstrate concepts of sustainability

\begin{tabular}{ll}
\hline Words & Number of times appeared \\
\hline Sustainability, sustainable & 22 \\
Social and socio-environmental responsibility & 10 \\
Sustainable development & 8 \\
Environment & 5 \\
Environmental management & 3 \\
Social capital & 3 \\
Green & 3 \\
Ecological & 1 \\
Natural resources & 1 \\
Environmental impact & 1 \\
Three pillars & 1 \\
Indicators of sustainability & 1 \\
ISO 14000 & 1 \\
Reverse logistics & 1 \\
Social innovation & 1 \\
Social dimension & 1 \\
Green IT & 1 \\
\hline
\end{tabular}

Source: Developed by the authors based on research data

Almeida and Kautzmann (2012), debates related to the area of sustainability lead to the education of professionals that understand, and have proactive attitudes towards, this issue.

After identifying which courses covered topics related to the theme in question, it was necessary to classify the courses of each program according to the type of research and also if the course belongs to some specific line of research, or if it is a general educational class. Table 4 demonstrates this classification.

Table 4 shows the variety of topics and nomenclatures that the Master's courses have. Each graduate program approaches the subject in a different way which is closely related to the multidisciplinary character of the subject. It can also be observed that in some programs, there is an only isolated course that speaks about the theme, and in others, the subject is presented in connection with specific content. According to the ideas of Almeida and Kautzmann (2012), there is a need to first open spaces in the curricula for an environmental theme, and later create informal links with other courses, and finally, as a greater goal, to foster the reworking of the courses, as we saw interesting examples of how to integrate the theme within other topics.

Another important finding is that in only one program (MBA 8) is the course that speaks to subjects related to sustainability classified as required for all students enrolled in the program; in the others, these courses are in a specific line of research, that is, a student can graduate from the program with having access to the topics of this theme. This shows that this subject is studied by people who have proximity and affinity with the theme and not as an important subject in the education of all professionals, independent of their area of activity. It is interesting to observe that in the MBA 3 program, there is a specific line of research to study sustainability that identifies the importance of this study for the science of Business Administration. 
Table 4 Classification of the courses that possess some relation to sustainability

\begin{tabular}{|c|c|c|c|}
\hline Master's & Course & Type of course & Line of research \\
\hline \multirow[t]{2}{*}{ MBA 1} & Information systems in organizations & Elective & Line of research management technology \\
\hline & Marketing administration & Elective & $\begin{array}{l}\text { Line of research organizations, market, } \\
\text { work }\end{array}$ \\
\hline MBA 2 & Third sector and cooperativism & Elective & $\begin{array}{l}\text { Line of research contemporary organiza- } \\
\text { tional studies }\end{array}$ \\
\hline \multirow[t]{6}{*}{ MBA 3} & $\begin{array}{l}\text { Research seminar in innovation, tech- } \\
\text { nology and sustainability }\end{array}$ & Elective & $\begin{array}{l}\text { Line of research innovation, technology } \\
\text { and sustainability }\end{array}$ \\
\hline & $\begin{array}{l}\text { Environmental management and com- } \\
\text { petitiveness }\end{array}$ & Elective & $\begin{array}{l}\text { Line of research innovation, technology } \\
\text { and sustainability }\end{array}$ \\
\hline & $\begin{array}{l}\text { Organizational and inter-organizational } \\
\text { strategies }\end{array}$ & Elective & $\begin{array}{l}\text { Line of research innovation, technology } \\
\text { and sustainability }\end{array}$ \\
\hline & $\begin{array}{l}\text { Epistemological, theoretical and } \\
\text { methodological discussions based on } \\
\text { complexity }\end{array}$ & Elective & $\begin{array}{l}\text { Line of research innovation, technology } \\
\text { and sustainability }\end{array}$ \\
\hline & $\begin{array}{l}\text { Sustainable development, strategy and } \\
\text { innovation in agribusiness }\end{array}$ & Elective & $\begin{array}{l}\text { Line of research innovation, technology } \\
\text { and sustainability }\end{array}$ \\
\hline & $\begin{array}{l}\text { From production to consumption: } \\
\text { competitiveness, innovation and } \\
\text { sustainability }\end{array}$ & Elective & $\begin{array}{l}\text { Line of research innovation, technology } \\
\text { and sustainability }\end{array}$ \\
\hline \multirow[t]{2}{*}{ MBA 4} & $\begin{array}{l}\text { Socio-environmental responsibility and } \\
\text { sustainability }\end{array}$ & Elective & Strategy in organizations \\
\hline & $\begin{array}{l}\text { Strategy for sustainable technological } \\
\text { innovation in organizations }\end{array}$ & Elective & Strategy in organizations \\
\hline \multirow[t]{3}{*}{ MBA 5} & Advanced topics in strategy & Elective & Strategic management \\
\hline & Strategic management & Elective & Strategic management \\
\hline & $\begin{array}{l}\text { Analysis of competitiveness and Sustain- } \\
\text { ability }\end{array}$ & Elective & Strategic management \\
\hline MBA 6 & None & - & - \\
\hline \multirow[t]{6}{*}{ MBA 7} & Sustainability and social responsibility & Elective & No specific line of research \\
\hline & Social perspectives in organizations & Elective & No specific line of research \\
\hline & Sustainable operations & Elective & No specific line of research \\
\hline & Innovation and entrepreneurship & Required & Innovation and competitiveness \\
\hline & $\begin{array}{l}\text { Environmental management and social } \\
\text { responsibility }\end{array}$ & Elective & No specific line of research \\
\hline & Social capital & Elective & No specific line of research \\
\hline \multirow[t]{4}{*}{ MBA 8} & Theory of organizations & Required & All lines of research \\
\hline & Sustainability in organizations & Elective & $\begin{array}{l}\text { Line of research competitiveness and } \\
\text { marketing }\end{array}$ \\
\hline & Product development & Elective & $\begin{array}{l}\text { Line of research competitiveness and } \\
\text { marketing }\end{array}$ \\
\hline & $\begin{array}{l}\text { Evaluation of environment impact in } \\
\text { projects }\end{array}$ & Elective & $\begin{array}{l}\text { Line of research competitiveness and } \\
\text { marketing }\end{array}$ \\
\hline
\end{tabular}

Source: Developed by the authors based on research data

If we relate Table 4 with the work of Figueiró and Raufflet (2015), we can see that the subjects of sustainability are being inserted into the programs; that is, the introduction of the subject is still carried out in a one-off and superficial manner, differently from the ideal, which would be that the integration of the theme in a way that the project in its entirety is planned in an integrated and interdisciplinary way. Thus, understanding which subjects are being related to the theme becomes of profound interest on the part of the authors of this study. Hence, we can obtain a greater understanding of how 
the integration of sustainability in graduate programs in Business Administration is occurring.

Therefore, after analyzing each course, we chose to identify which topics are closely related to sustainability within the MBA programs, in the syllabi that are related to the theme we sought to analyze with which other subjects are also integrated. Thus, Table 5 came about.

Table 5 shows the topics that are most related to the theme of sustainability, and which topics are described in the courses that make a connection with sustainability, within the courses. In this way is mentioned the number of times that a particular topic is described in course programs. It can been seen that the topics that most related to the theme are those that maintain the logic of the market: strategy, innovation and competitiveness (mentioned five times each). The other issues were mentioned only once each, indicating the variability of related issues. It was observed that the topics that spark a deeper reflection upon the theme, like critical vision and complexity, are only covered in just one course among all of the studied programs, suggesting that reflective and critical issues are not often studied.

It was used public data in sucupira platform to perform the analysis of the pedagogical projects and disciplines of each researched graduate. Thus, this is a limitation of this study that chose this type of data rather than information collected directly on each master.

\section{Conclusions}

With this study, we can conclude that the discourse of sustainability is already found in the majority of the pedagogical projects of Master's programs and that courses related to education for sustainable development are present in seven of the eight MBA programs in Rio Grande do Sul. However, these courses are related to specific lines of research, and are not part of the general education of students. This means that programs we

Table 5 Topics related to sustainability

\begin{tabular}{ll}
\hline Words & Number of courses that relate topics to sustainability \\
\hline Strategy & 5 \\
Innovation & 5 \\
Competitiveness & 5 \\
Social development & 1 \\
Systematic vision & 1 \\
Critical vision & 1 \\
Entrepreneurship & 1 \\
Logistics & 1 \\
Multidisciplinary approach & 1 \\
Internationalization & 1 \\
Complexity & 1 \\
Project management & 1 \\
Product development & 1 \\
Marketing & 1 \\
Information technology & 1
\end{tabular}

Source: Developed by the authors based on research data 
studied do not have, among its objectives, the goal of educating prepared professionals for the reality of sustainability. It is of utmost importance that the courses related to this theme be required within the curriculum, so that students have the knowledge and skills to conduct sustainable development projects and actions in their work environments.

During the study, it was possible to perceive that the programs posses a curricular structure with a focus on traditional MBA education courses, such as Marketing, Human Resources, and Finance, leaving space for topics that have characteristics of content integration, and that involve questions of complexity that are important for future managers and Business Administration professors. Adapting the curricular structure of offered courses does not mean merely to update the approaches of the incorporated areas into the existing structures, but also to have a critical analysis of the situations with which the future professionals will be involved; this requires a multidisciplinary character of programs, offering students a quality program.

It is noticed that the programs, even in a rudimentary way, already notice the need to insert concepts as points Clugston (2004) and Tilbury (2004), but this integration does not take place in an integrated manner throughout the course restricted to a discipline, collaborating with studies of Benn and Dunphy (2009) or even to a specific research area.

Besides integrating the theme into the syllabi of individual courses, universities should provide the experience of sustainability to the student, making them conscious of the subsequent effects of their daily actions, as suggested by Brandli et al. (2014). Thus, they can see that sustainability is relevant in various activities that are part of the daily life of a Business Administration professional. Due to their strategic position within institutions, these professionals have the possibility to introduce and expand the topic in their work environment.

As a suggestion for further research projects, we identified the need to interview the administrators of the MBA programs to establish relationships between the pedagogical projects and the goals of the administration of the programs. It should be noted that the authors of this article are developing investigations with the intent of widening the scope of the approach presented here.

\begin{abstract}
Abbreviations
ART: Artigo (article); CAPES: Coordenação de Aperfeiçoamento de Pessoal de Nível Superior (Coordination for the Improvement of Higher Education Personnel); DS: Desenvolvimento Sustentável (sustainable development); EA: Educação Ambiental (Environmental Education); EPS: Educação para Sustentabilidade (Education for Sustainability); EUA: Estados Unidos da América (United States of America); IES: Instituições de Ensino Superior (Institutes of Higher Education); MBA: Master's in Business Administration; MEC: Ministério da Educação (Ministry of Education); N: Número (number); PPGA: Programa de Pós-graduação em Administração (Graduate Program in Administration); UNECE: United Nations Economic Commission for Europe; UNESCO: Organização das Nações Unidas para a Educação, Ciência e Cultura (United Nations Educational, Scientific and Cultural Organization).
\end{abstract}

Authors' contributions

CSM participated in the methodological choice and the design of the manuscript, and the analysis of data. MT participated in the methodological choice and design and made contributions to the text. ACC made contributions to the text. All authors read and approved the final manuscript.

Author details

${ }^{1}$ Federal University of Santa Maria and Federal University of Pampa, Av. Pedro Anunciação, s/nº - Vila Batista District, Caçapava do Sul, RS 96570-000, Brazil. ${ }^{2}$ Federal University of Santa Maria, Av. Roraima, 1000, 74 C, University City-Camobi District, Santa Maria, RS 97105-900, Brazil. 


\section{Competing interests}

The authors declare that they have no financial competing interests and non-financial competing interests (political, personal, religious, ideological, academic, intellectual, commercial or any other) in relation to this manuscript.

Received: 3 November 2015 Accepted: 25 February 2016

Published online: 09 March 2016

\section{References}

Almeida JCT, Kautzmann RM (2012) A educação ambiental (EA) na universidade e na empresa. Rev Ciênc Ambient 6(1):117-136

Amorim RCM, Custódio LS (2010) A necessidade de estruturação dos pressupostos da sustentabilidade e da responsabilidade social empresarial para as realidades do ensino/aprendizagem nos cursos de administração.Revista Científica do Departamento de Ciências Jurídicas, Políticas e Gerenciais da UNI-BH, vol 3, no 1

Barbieri JC (2004) Educação ambiental e a gestão ambiental em cursos de graduação em administração: objetivos, desafios e propostas. Rev Adm Pública 38(6):919-946

Bardin L (2004) Análise de conteúdo, 3rd edn. Edições, Lisboa, p 70

Barth M, Rieckmann M (2012) Academic staff development as a catalyst for curriculum change towards education for sustainable development: an output perspective. J Clean Prod 26:28-36

Benn S, Dunphy D (2009) Action research as an approach to integrating sustainability into MBA programs: an exploratory study. J Manag Educ 33(3):276-295

Brandli et al (2014) Evaluation of sustainability using the AISHE instrument: case study in a Brazilian University. Braz J Sci Technol 1:4

Brasil (1999) Lei n 9.795, de 27 de abril de 1999. Institui a Política Nacional de Educação Ambiental. Diário Oficial da União, Brasília, seção 1, pp 1-4

Bursztyn M, Drummond JA (2009) Desenvolvimento sustentável: uma ideia com linhagem e legado. Soc Estado Bras 24(1):11-15

Clugston RF (2004) Forewod. In: Corcoran PB, Wals AEJ (eds) Higher educations and the challenge of sustainability: problematics, promice and practice. Kluwer Academic Press, Dordrecht

de Andrade ROB, Tachizawa T, Carvalho AB (2000) Gestão ambiental. Makron Books, São Paulo

de Castro RS (ed) (2000) Sociedade e Meio Ambiente: A Educação Ambiental em Debate. Cortez, São Paulo

Demajorovick J, Silva HCO (2012) Formação interdisciplinar e sustentabilidade em cursos de administração: desafios e perspectivas. Rev Adm Mackenzie São Paulo (RAM) 13(5):39-64

Figueiró PS, Raufflet E (2015) Sustainability in higher education: a systematic review with focus on management education. J Clean Prod. doi:10.1016/j.jclepro.2015.04.118

Fouto ARF (2002) O papel das universidades rumo ao desenvolvimento sustentável: das relações internacionais às práticas locais, Mestrado em Gestão e Políticas Ambientais, Relações Internacionais do Ambiente, Universidade Nova de Lisboa

Godoy AS, Brunstein J, Fischer TMD (2013).Introdução ao fórum temático. sustentabilidade nas escolas de administração: tensões e desafios. Rev Adm Mackenzie (RAM) 14(3), Edição Especial:14-25

Gonçalves-Dias SLF, Herrera CB, de Cruz SMT (2013) Desafios (e dilemas) para inserir "sustentabilidade" nos currículos de administração: um estudo de caso. Rev Adm Mackenzie (RAM) 14(3):119-153

Hesselink F, Van Kempen PP, Wals A (2000) ESDebate. International debate on education for sustainable development. IUCN, Gland

Jacobi P (1997) Meio ambiente urbano e sustentabilidade: alguns elementos para a reflexão. In: Cavalcanti C (ed) Meio ambiente, desenvolvimento sustentável e políticas públicas. Cortez, São Paulo, pp 384-390

Jacobi PR, Raufflet E, de Arruda MP (2011) Educação para a sustentabilidade nos cursos de administração: Reflexão sobre paradigmas e práticas. Rev Adm Mackenzie (RAM) 12(3):21-50

Latif M, Jiji LM, Schonfeld IS, Smith GA (2015) Capstone interdisciplinary team project: a requirement for the MS in sustainability degree. Int J Sustain High Educ 16(2):187-199

Junior FH, Dias BG, Zellmeister LM, Brinholi CF (2014) A Sustentabilidade no Ensino de Administração: Proposta de um Currículo Básico para o Curso de Graduação. In: Anais do XXXVIII Encontro da ANPAD, Rio de Janeiro

Lauder H, Brown P, Dillabough JA, Halsey AH (2006) Education, globalization and social change. Oxford University Press, Oxford

Leal Filho W (2011) About the role of universities and their contribution to sustainable development. High Educ Policy 24:427-438

Mochizuki Y, Fadeeva Z (2010) Competencies for sustainable development and sustainability: significance and challenges for ESD. Int J Sustain High Educ 11(4):391-403

Paulo RRD, Ferolla LM (2010) Ensaio sobre a Educação Ambiental na formação de gestores. FEA/USP. In: Encontro nacional de gestão empresarial e meio ambiente, 2010. Anais ENGEMA, FEA/USP, São Paulo

Roesch SMA (2005) Projetos de estágio e de pesquisa em administração: guia para estágios, trabalhos de conclusão, dissertações e estudos de caso, 3rd edn. Atlas, São Paulo

Salgado M, Cantarino AAA (2006) O papel das instituições de ensino superior na formação socioambiental dos futuros profissionais. In: Encontro Nacional de Engenharia de Produção. Recuperado em 31 outubro, 2012. http://www. abepro.org.br/biblioteca/ENEGEP2006 TR560372 8269.pdf

Segalàs DF-B, Mulder KF (2010) What do engineering students learn in sustainability courses? The effect of the pedagogical approach. J Clean Prod 18(3):275-284

Sleurs W (2015) Competencies for ESD (education for sustainable development) teachers: a framework to integrate ESD in the curriculum of teacher training institutes, UNECE, 2008. http://www.unece.org (20 Jan 2015) 
Springett D (2005) Educations for sustainability in the business studies curriculim: a call for a critical agenda. Bus Strategy Environ 14(3):146-159

Springett Delyse, Kearins Kate (2005) Educating for sustainability: an imperative for action. Bus Strategy Environ 14(3):143-145

Sterling S, Thomas I (2006) Education for sustainability: the role of capabilities in guiding university curricula. Int J Innov Sustain Dev 1:349-370. doi:10.1504/IJSD.2006.013735

Tilbury D (2004) No title environmental education for sustainability: a force for change in higher education. In: Corcoran PB, Wals AEJ (eds) Higher education and the challenge of sustainability: problematics, promise and practice. Kluwer, Dordrecht, pp 97-112

Tikhomirova $\mathrm{N}$ et al (2015) Problem-based learning in development a Msc curriculum on sustainable development. In: Transformative approaches to sustainable development at universities, world sustainable series. doi:10.1007/978-3-319-08837-2_32

UNESCO (1999) Educação para um futuro sustentável: uma visão transdisciplinar para uma ação compartilhada. IBAM, Brasilia

UNESCO (2005) Década da Educação das Nações Unidas para um desenvolvimento sustentável, 2005-2014: documento final do esquema internacional de implementação. Brasília, UNESCO. http://unesdoc.unesco.org/ images/0013/001399 (22 Sept 2014)

Venzke CS, Nascimento LF (2013) Caminhos e desafios para a inserção da sustentabilidade socioambiental na formação do administrador brasileiro. Rev Adm Mackenzie (RAM) 14(3), ed. especial

Wright TSA (2004) The evolution of sustainability declarations in higher educations. In: Corcoran PB, Wals AEJ (eds) Higher educations and the challenge of sustainability: problematics, promice and practice. Kluwer, Dordrecht

\section{Submit your manuscript to a SpringerOpen ${ }^{\circ}$ journal and benefit from:}

- Convenient online submission

- Rigorous peer review

- Immediate publication on acceptance

- Open access: articles freely available online

- High visibility within the field

- Retaining the copyright to your article

Submit your next manuscript at $\mathbf{s p r i n g e r o p e n . c o m ~}$ 